\title{
The Top Hundred Papers of Uveitis Research. A Bibliometric Analysis
}

\author{
Ueberschaar $\mathbf{J}^{1}$, Schargus ${ }^{2,3}$, Katz $\mathrm{T}^{1}$, Kromer $\mathbf{R}^{1}$, Vasyl Druchkiv ${ }^{1,4}$ and Frings $\mathrm{A}^{2 *}$ \\ ${ }^{1}$ Department of Ophthalmology, University Hospital Hamburg-Eppendorf, Germany \\ ${ }^{2}$ Department of Ophthalmology, Heinrich-Heine-University Düsseldorf, Germany \\ ${ }^{3}$ Eye Clinic Schweinfurt-Gerolzhofen, Gerolzhofen, Germany \\ ${ }^{4}$ Clínica Baviera, Valencia, Spain
}

Submission: April 04, 2018; Published: May 30, 2018

*Corresponding author: Andreas Frings, Department of Ophthalmology, Heinrich-Heine-University Düsseldorf, Moorenstraße 5, 40225 Düsseldorf, Germany, Tel: + 49-0211-81 17333;Fax: +49-0211-81 17340; Email: andi.frings@gmail.com

Abstract

Purpose: To identify and evaluate the 100 most frequently cited articles containing uveitis research

Methods: Utilizing Databases, specifically of the Institute for Scientific Information, we recognized all issued articles relevant to the topic of uveitis research. All articles containing uveitis research, a publication date ranging from 1900 to September 2016, and had been cited at least 100 times, were included. The top 100 of that list matching the criteria from the above were then further analyzed.

Results: Out of the 100 most-cited articles the most cited one in uveitis research with 923 citations was entitled Standardization of uveitis nomenclature for reporting clinical data. A result of the First International Workshop (Jabs et al.). Citations ranged from 106 to 923 and the two main focus areas were clinical and basic research articles. The leading countries of origin were the U.S. followed by the United Kingdom. Most articles represented Level-III evidence, followed by Level IIb and IV.

Conclusions: Our present study demonstrates that the majority $(n=54)$ of the top ranked articles were published in six of the top ranked journals. Four of these journals originated in the U.S. and one each of these originated in the Netherlands and the U.K. Younger case studies had higher citation rate (in 2015) as older studies. The biggest portion of articles represented Level-III clinical outcome studies implicating that even smaller case series or cohort studies could gain attention.

Keywords: Bibliometrics; Scientometrics; Uveitis

\section{Introduction}

Competent scientific publication has experienced major developments over the last decade [1]. Rapid changes make electronic journal submission and publication as well as access to periodicals increasingly simple [1]. A "Citation" is a mean to relegate to a peer-reviewed article in another article. So a citation recognizes the importance to a topic of interest from one author in which the citation appears [2,3]. Consequently, a citation is considered a tool of acknowledgment one article has earned in its area of research. By using citation analysis in selective journals of certain topics, it has become a favored method to evaluate the citation impact of a journal, article or author [4-8]. Citation analysis establishes the relative significance of medical journals through the impact factor, which is recognized based on the ratio of the number of citable items published in the same two years [9-11]. Bibliometric science is described as a statistical and quantitative analysis with the intention of investigating the scientific impact and characteristic of publications within a study field [12]. This present study is following the approach of Eugene Garfield, the founder of bibliometrics and scientometrics, who published its first bibliometric article for JAMA (The Journal of American Medical Association) in 1987 [13]. Bibliometric studies in various medical areas have been published and a tradition of publishing such articles has developed over the last years [12]. The purpose of this study is to provide a better understanding of citation classics and highlighting major intellectual milestones in the field of uveitis research. Therefore the 100-most cited papers in uveitis research were identified through an extensive search of literature by using validated methods from previously published bibliometric studies.

\section{Materials and Methods}

For this bibliographic study, database platforms, specifically the Institute for Scientific Information (ISI) Web of knowledge databases (Thomson Reuters Web of Science core collection and 


\section{JOJ Ophthalmology}

MEDLINE), were used as a tool to provide a bibliographic listing of journals. The deciding factor on which journals to search, was made with the Journal Citation Reports database, which ranks journals according to impact factor. The overall search was conducted in September 2016. The topic of the search was "Uveitis" with a publication range from 1900 to 2016.The ranking and searching options in the Web of Knowledge were utilized to list all articles from each journal according to its number of citations, and then were individually man-searched for those articles that had no relevancy to uveitis research. The outcome was listed from most cited to least cited and those with implications in uveitis research were selected for the study, whether they were published in surgical or non-surgical, in ophthalmology or non- ophthalmology journals.
The 100 articles matching the search criteria were then further analyzed by two independent investigators (JU; AF) for retrieval of the journal name, publication date, first and last authors, year of publication, geographic origin, total number of citations of the article, overall citation rate (total citations//article age), current citation rate (measured as the number of citations in the year 2015), research nature (surgical management, medical treatment, diagnosis, epidemiology or others), and level of evidence (I through IV for clinical and review articles (Table 1)). The two investigators disagreed regarding the characteristics of 8articles; these were re-evaluated and discussed with a third investigator (RK). This method has been exercised in a range of previous publications on bibliometric data $[6,12,14]$.

Table 1: Level of Evidence by Study Type (based on $<<$ Level of Evidence $>>$ published online from German Network for Evidence-based Medicine.

\begin{tabular}{|c|c|c|}
\hline Level & & Rating Criteria \\
\hline \multirow{2}{*}{ I } & la & $\begin{array}{c}\text { Evidence obtained from a systematic review of relevant randomized controlled trials (including meta- } \\
\text { analysis) }\end{array}$ \\
\cline { 2 - 3 } & Ib & Evidence obtained from at least one properly designed randomized, controlled trial \\
\hline \multirow{2}{*}{ II } & Ila & Evidence obtained from at least one well-designed controlled trial without randomization \\
\cline { 2 - 3 } & $\mathrm{Ilb}$ & Evidence obtained from one well-designed, pseudo-experimental trial \\
\hline III & & Evidence obtained from a well-designed, non-experimental descriptive trial \\
\hline IV & & Evidence obtained from case reports, expert opinion, consensus conference \\
\hline
\end{tabular}

(http://www.ebmnetzwerk.de/was-ist-ebm/images/evidenzklassen.jpg/view. Accessed October 30, 2016.)

The Shapiro-Wilk method was applied to test the distribution of individual variables for normality. Normally distributed data are presented as the mean and the standard deviation, and skewed data are presented as the median and the range. For plotting the whiskers and the outliers, the Turkey method was applied. One-way analysis of variance (ANOVA) was used to test for differences involving normally distributed data, and the Kruskal-Wallis test was used for skewed data. For pair wise comparisons, the p-values were aligned according to either the Bonferroni post-hoc test or the Mann-Whitney U test to adjust for the performance of different statistical analysis. The Spearman rank correlation was utilized as a measurement for correlations among variables. With the two-tailed test a p-value $\leq 0.05$ was considered statistically significant.

\section{Results}

A total of 13,848 entitled articles associated with uveitis research were listed in peer-reviewed journals in the ISI WEB of Knowledge (September 2016), and 1.9\% ( $n=260)$ had at least 100 citations. The top 100 most-cited articles (Table 2) possessed between 106 and 923 citations per article and varied in terms of the publication date from 1946 to 2011. Despite no inflicted language restrictions during our research, the results showed that all articles had been published in English. The number of clinical research amounted to fifty-three of the 100 articles, whereas 33 were basic research; there was no significant relationship in these two categories according to total citations per article (median=137 [range $=106$ to 399] and median 141 [range $=106$ to 524], respectively; $p=1.000$; Table 3 , Figure 1 ).

Table 2: The 100 Most-Cited Articles in Uveitis Research.

\begin{tabular}{|c|c|c|c|c|}
\hline Rank & Citations & Article & $\begin{array}{c}\text { Citations/Year Since } \\
\text { Publication }\end{array}$ & Citations in 2015 \\
\hline 1 & 923 & $\begin{array}{c}\text { Standardization of uveitis nomenclature for reporting clinical data. } \\
\text { Results of the First International Workshop }\end{array}$ & 76,92 & 135 \\
\hline 2 & 913 & Current concepts - Behcet's disease & 50,72 & 62 \\
\hline 3 & 524 & $\begin{array}{c}\text { Experimental allergic uveitis. Isolation, characterization, and } \\
\text { localization of a soluble uveitopathogenic antigen from bovine } \\
\text { retina }\end{array}$ & 6 & 43,1 \\
\hline 4 & 429 & $\begin{array}{c}\mathrm{T}(\mathrm{H}) 17 \text { cells contribute to uveitis and scleritis and are expanded } \\
\text { by IL-2 and inhibited by IL-27/STAT1 }\end{array}$ & 51 \\
\hline
\end{tabular}




\begin{tabular}{|c|c|c|c|c|}
\hline 5 & 404 & Endotoxin-induced uveitis in rats as a model for human disease & 10,92 & 14 \\
\hline 6 & 399 & $\begin{array}{c}\text { Renal histopathologic alterations in patients treated with } \\
\text { cyclosporine for uveitis }\end{array}$ & 12,87 & 2 \\
\hline 7 & 392 & Vascular involvement in Behçet's disease & 15,68 & 11 \\
\hline 8 & 390 & $\begin{array}{l}\text { International Uveitis Study Group recommendations for the } \\
\text { evaluation of intraocular inflammatory disease }\end{array}$ & 13 & 19 \\
\hline 9 & 388 & Signs and symptoms of uveitis. 1. anterior uveitis & 6.69 & 9 \\
\hline 10 & 368 & $\begin{array}{l}\text { Either a Th17 or a Th1 effector response can drive autoimmunity: } \\
\text { conditions of disease induction affect dominant }\end{array}$ & & \\
\hline $\begin{array}{l}\text { effector } \\
\text { category }\end{array}$ & 40.89 & 47 & & \\
\hline 11 & 344 & $\begin{array}{l}\text { Effects of AIN457, a Fully Human Antibody to Interleukin-17A, on } \\
\text { Psoriasis, Rheumatoid Arthritis, and Uveitis }\end{array}$ & 49,14 & 69 \\
\hline 12 & 337 & $\begin{array}{l}\text { Causes and frequency of blindness in patients with intraocular } \\
\text { inflammatory disease }\end{array}$ & 16,05 & 30 \\
\hline 13 & 332 & Acute anterior uveitis and HL-A 27 & 7,55 & 9 \\
\hline 14 & 305 & $\begin{array}{l}\text { Age at disease onset and diagnosis delay in HLA-B27 negative vs. } \\
\text { positive patients with ankylosing spondylitis }\end{array}$ & 21,79 & 37 \\
\hline 15 & 300 & Human T cell leukemia virus type I (HTLV-I) and human diseases & 15 & 7 \\
\hline 16 & 272 & Vogt-koyanagi-harada syndrome & 12,36 & 20 \\
\hline 17 & 263 & $\begin{array}{l}\text { Incidence and prevalence of uveitis in Northern California - The } \\
\text { Northern California Epidemiology of Uveitis Study }\end{array}$ & 20,23 & 34 \\
\hline 18 & 262 & $\begin{array}{l}\text { The prevalence of extraintestinal diseases in inflammatory bowel } \\
\text { disease: A population-based study }\end{array}$ & 16,38 & 25 \\
\hline 19 & 246 & $\begin{array}{l}\text { Safety and efficacy of intravitreal triamcinolone for cystoid } \\
\text { macular oedema in uveitis }\end{array}$ & 15,38 & 10 \\
\hline 20 & 225 & Risks of intravitreous injection: A comprehensive review & 17,31 & 25 \\
\hline 21 & 218 & $\begin{array}{l}\text { Standardization of vitreal inflammatory activity in intermediate } \\
\text { and posterior uveitis }\end{array}$ & 6,81 & 20 \\
\hline 22 & 217 & HTLV-I uveitis: a distinct clinical entity caused by HTLV-I & 8,68 & 3 \\
\hline 23 & 217 & $\begin{array}{l}\text { Acanthamoeba polyphaga keratitis and Acenthamoeba uveitis } \\
\text { associated with fatal meningoencephalitis }\end{array}$ & 5,17 & 5 \\
\hline 24 & 203 & $\begin{array}{l}\text { Differential efficacy of tumor necrosis factor inhibition in } \\
\text { the management of inflammatory eye disease and associated } \\
\text { rheumatic disease }\end{array}$ & 12,69 & 6 \\
\hline
\end{tabular}

Fourteen articles were classified as review article. Review articles also did not show a significant relationship with respect to total citations per article compared to clinical research articles (median=286 [range=107 to 923]; p=1.000 and1.000; Table 3, Figure 1).

Table 3: Citations per Type of Article.

\begin{tabular}{|c|c|c|c|c|c|c|c|}
\hline & \multicolumn{4}{|c|}{ Citations per Type of Article } & \multicolumn{3}{|c|}{$\mathbf{P}^{*}$} \\
\hline & $\mathbf{N}$ & $\begin{array}{c}\text { Range (Min/ } \\
\text { Max) }\end{array}$ & $\operatorname{Mean}( \pm \mathrm{SD})$ & $\begin{array}{c}\text { Median(Q25/ } \\
\text { Q75) }\end{array}$ & Gr1 vs Gr2 & Gr1 vs Gr3 & Gr2 vs Gr3 \\
\hline $\begin{array}{l}\text { Basic Research } \\
\text { (Gr1) }\end{array}$ & 33 & $106 / 524$ & $194( \pm 115)$ & 141(118/198) & \multirow{3}{*}{1} & \multirow{3}{*}{1} & \multirow{3}{*}{1} \\
\hline $\begin{array}{c}\text { Clinical } \\
\text { Research (Gr2) }\end{array}$ & 53 & $106 / 399$ & $168( \pm 67)$ & $137(119 / 197)$ & & & \\
\hline $\begin{array}{l}\text { Review Article } \\
\text { (Gr3) }\end{array}$ & 14 & $107 / 923$ & $268( \pm 284)$ & $150(121 / 388)$ & & & \\
\hline Total & 100 & $106 / 923$ & $193( \pm 137)$ & $140(119 / 202)$ & \multicolumn{3}{|c|}{ *Mann-Whitney Test } \\
\hline
\end{tabular}




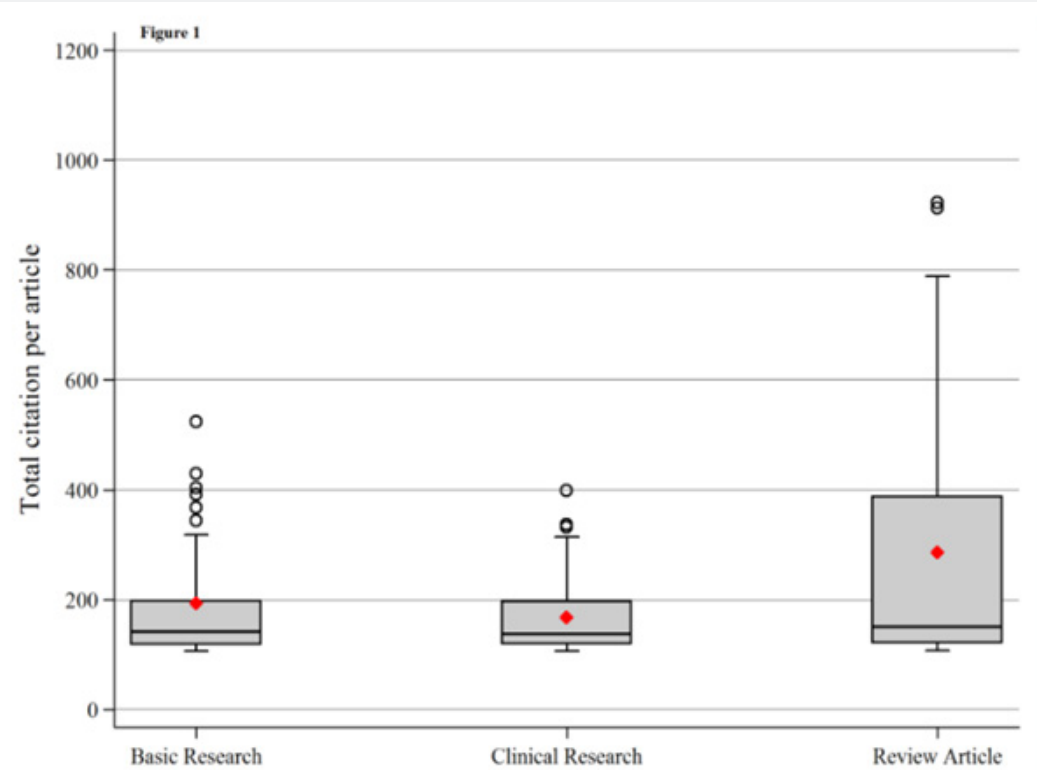

Figure 1: Bar graph showing the number of citations (and standard deviation) for the most-cited articles according to type of article (clinical or basic research, review article).

Red point= Mean value

Box: Lower line= 25th quartile;

Upper line= 75th quartile;

black line in box= Median value

White points $=$ Outliers.

The most articles $(n=53)$ were published in the field of clinical research. Among them were articles related to medical treatment $(n=20)$ followed by epidemiology $(n=17)$, diagnosis $(\mathrm{n}=11)$ and surgical treatment $(\mathrm{n}=5)$.

For clinical research and review articles, the level of evidence was defined. Of these, the greatest number of articles ( $n=26$, with a median of 162 [range=106 to 913] citations per article) represented Level-III evidence, followed by Level-IIb ( $\mathrm{n}=22$ with a median of 131 [range $=107$ to 332] citations), Level IV ( $\mathrm{n}=9$ with 169 [range=112 to 923] citations), Level $\mathrm{Ib}(\mathrm{n}=5$ with 183 [range $=114$ to 399] citations), Level-IIa ( $n=3$ with 115 [range=109 to 156] citations), and Level-Ia ( $\mathrm{n}=2$ with188 [range $=178$ to197] citations) (Table 4 \& Figure 2). The KruskalWallis test showed no significant differences in citations per article among the various levels of evidence $(p=0.360)$.

Table 4: Citations per Level of Evidence (clinical + review articles $(n=67))$.

\begin{tabular}{|c|c|c|c|c|}
\hline & $\mathbf{N}$ & Range(Min/Max) & Mean $( \pm$ SD) & Median (Q25/Q75) \\
\hline Ia & 2 & $178 / 197$ & $188( \pm 13)$ & $188(178 / 197)$ \\
\hline Ib & 5 & $114 / 399$ & $206( \pm 113)$ & $183(136 / 200)$ \\
\hline Iia & 3 & $109 / 156$ & $127( \pm 26)$ & $115(109 / 156)$ \\
\hline Iib & 22 & $107 / 332$ & $152( \pm 54)$ & $162(119 / 173)$ \\
\hline III & 26 & $105 / 913$ & $200( \pm 160)$ & $169(125 / 388)$ \\
\hline IV & 9 & $112 / 923$ & $286( \pm 263)$ & $137(119 / 203)$ \\
\hline Total & 67 & $106 / 923$ & $456( \pm 278)$ & 1317 \\
\hline
\end{tabular}




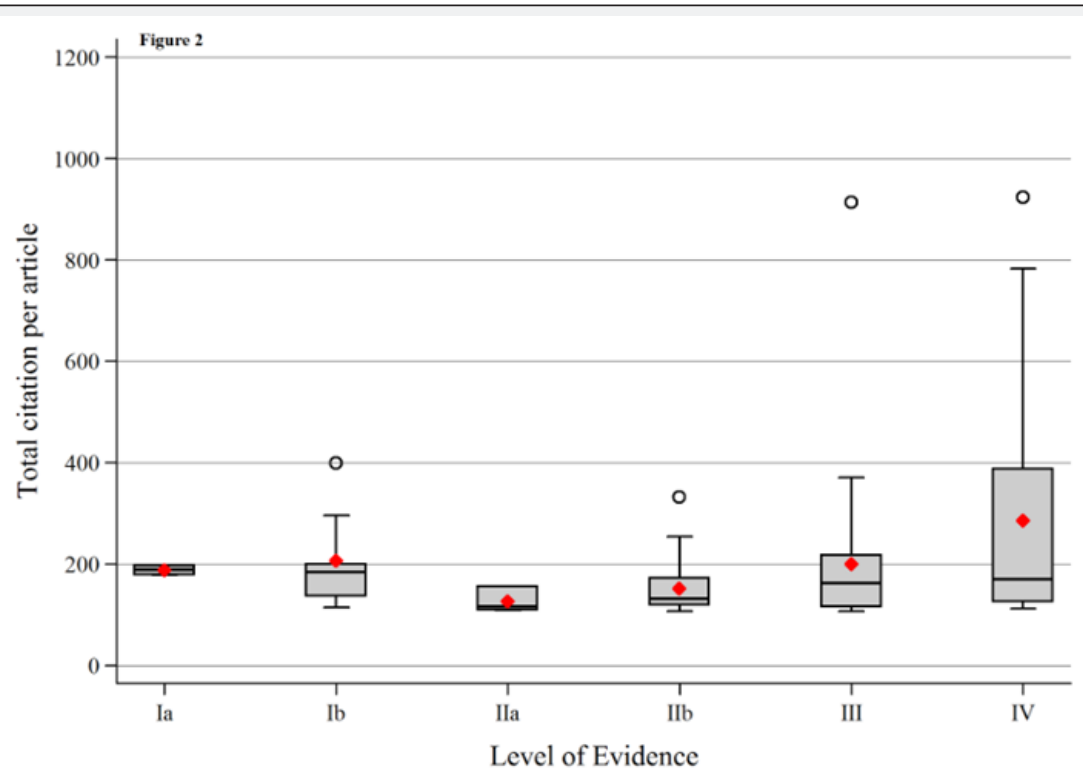

Figure 2: Bar graph showing the number of citations (and standard deviation) for the most-cited articles according to the level of evidence (based on $<<$ Level of Evidence $>>$ published online from German Network for Evidence-based Medicine.

Red point= Mean valueBox: Lower line= 25th quartile; Upper line= 75th quartile; black line in box= Median value White points= Outliers.

The greatest number of articles from the list $(n=39)$ were published in the 2000s followed by the 1990s $(n=36)$ and the 1980s (n=13) (Figure 3B). The total number of citations per articletype was greatest for articles published in the 2000s (366) followed by the 1990s (139) and the 1980s (75) (Figure 3A).
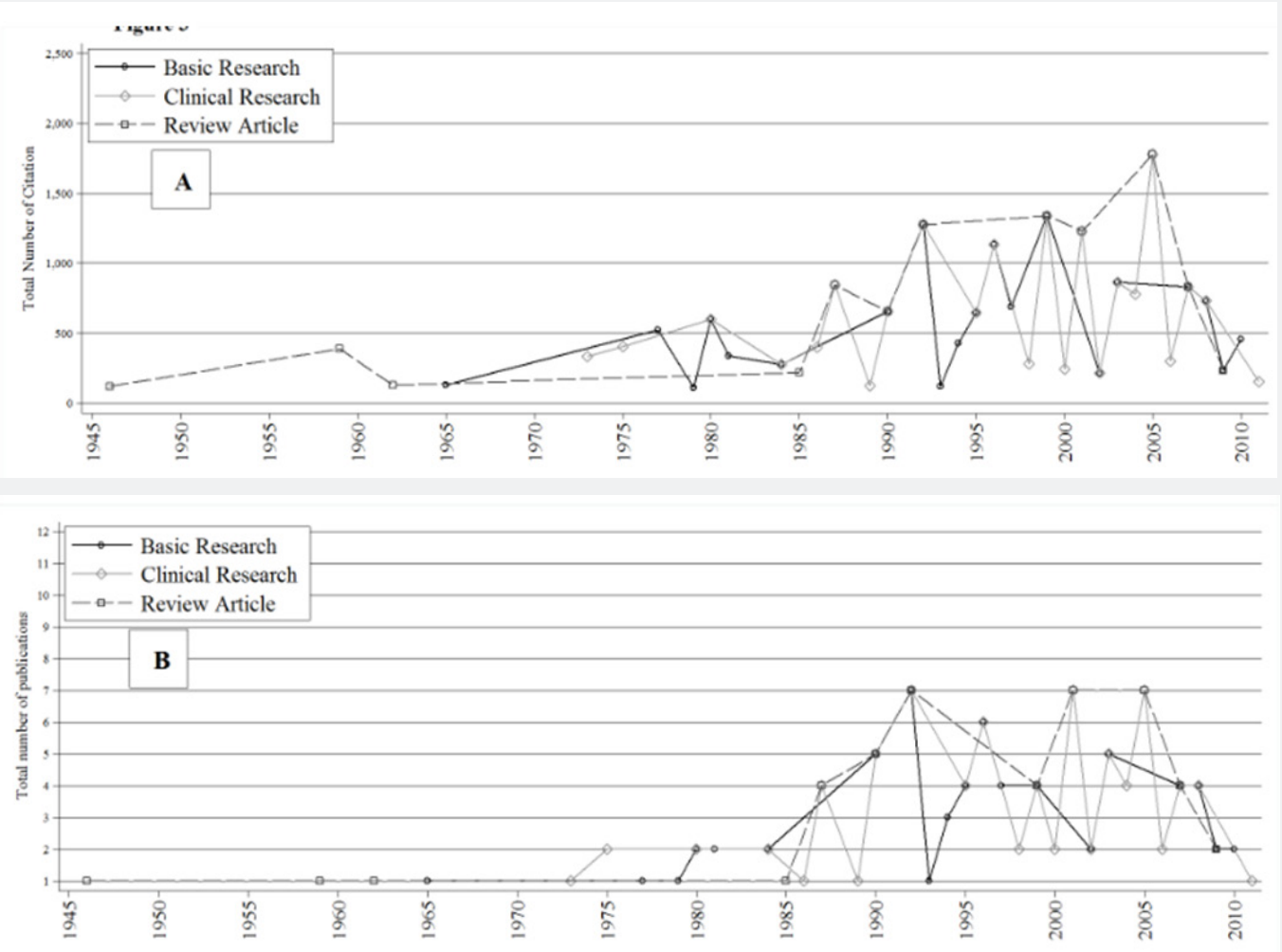

Figure 3: For each type of article (clinical or basic research, review article) the (A) total number of citations and the (B) total number of publications according to publication year are visualized. 
The overall citation rate of an article was independent of its publication date $(r<0.001, p=0.142$, Mann-Kendall test, Figure $4 \mathrm{~B}$ ). However, the current citation rate (measured as the number of its citations in 2015) of an article indicated that articles published after 2000 were more likely cited in recent years. This correlation was statistically significant $(r=0.41, p<0.001$, MannKendall test, Figure 4A).

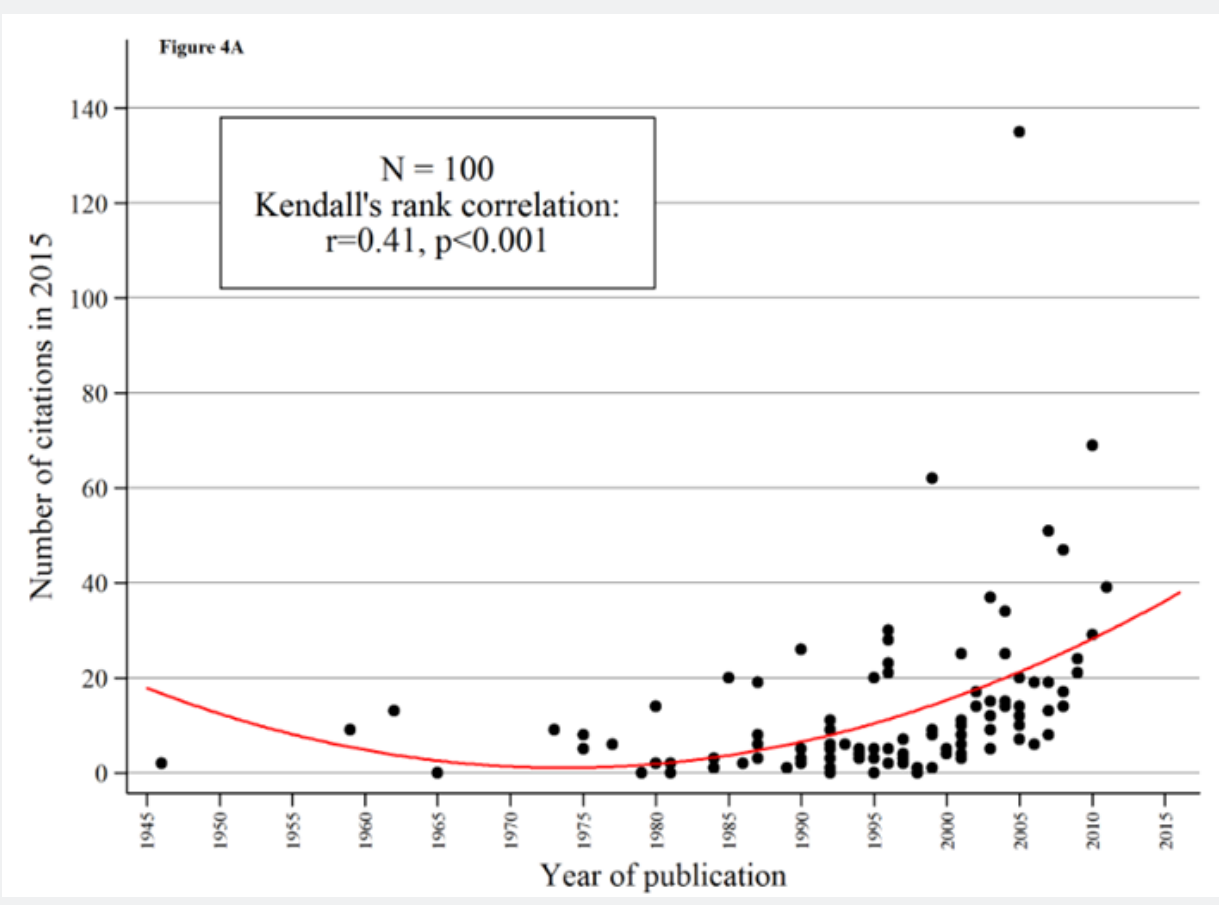

Figure 4A: Current (2015= last full year) citation rate.

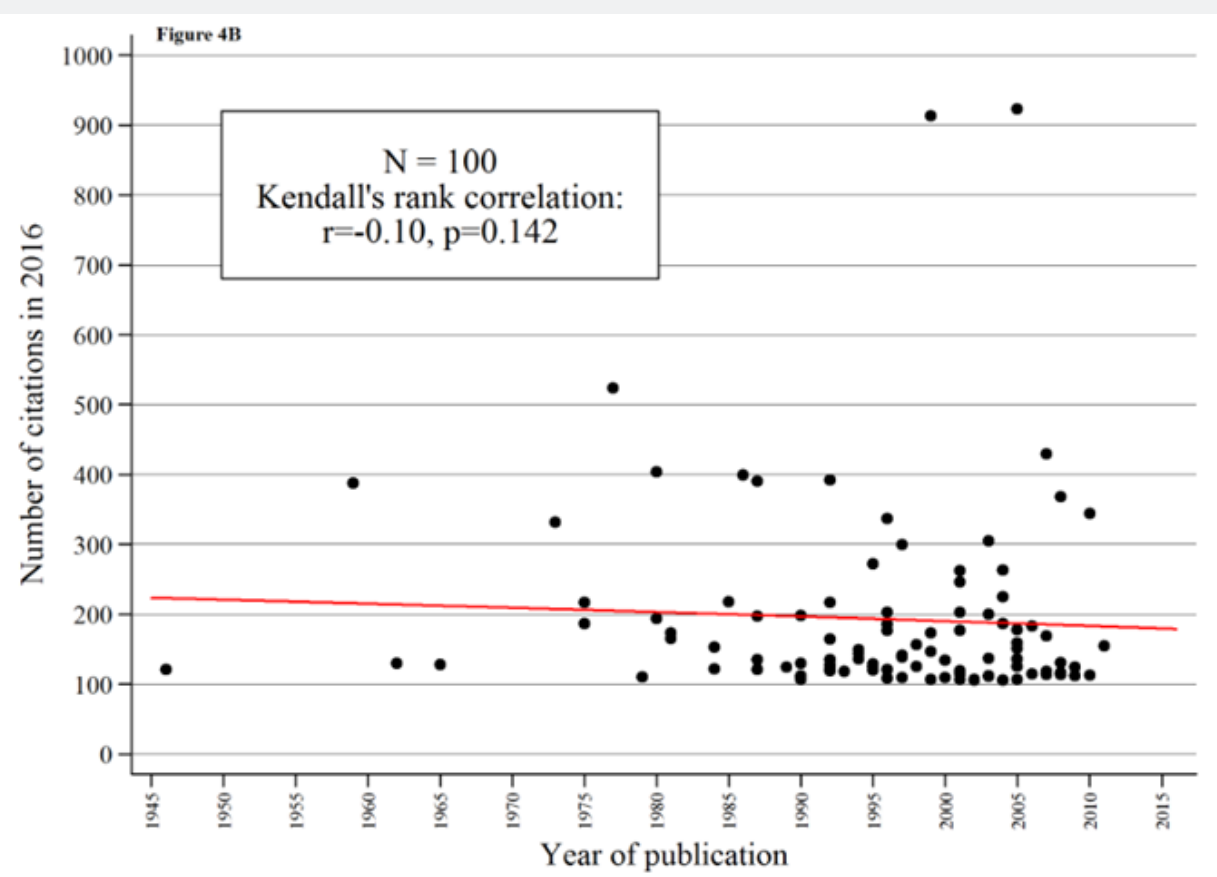

Figure 4B: Overall citation rate since publication for the most-cited articles according to the publication date of the article. 


\section{JOJ Ophthalmology}

The 100 most-cited articles were published in 36 different Journals (Table 5). Eighteen of the 36 Journals were American, 5 were British, 2 Journals each were Turkish, Canadian, Japanese and Australian and 1 Journal each was German, Swiss, Dutch and Spanish; 13 fell under the ophthalmology category and 23 were medical journals without a focus on ophthalmology.

Table 5: Journals in which the 100 Most-Cited Articles were published.

\begin{tabular}{|c|c|c|}
\hline Journal & $\begin{array}{c}\text { No. of } \\
\text { Articles }\end{array}$ & First Issue \\
\hline Ophthalmology & 13 & 1980 \\
\hline American Journal Of Ophthalmology & 12 & 1884 \\
\hline Archives Of Ophthalmology & 8 & 1929 \\
\hline $\begin{array}{c}\text { Investigative Ophthalmology \& Visual } \\
\text { Science }\end{array}$ & 7 & 1976 \\
\hline Journal Of Immunology & 7 & 1915 \\
\hline British Journal Of Ophthalmology & 7 & 1917 \\
\hline Survey Of Ophthalmology & 5 & 1980 \\
\hline Arthritis And Rheumatism & 4 & 1958 \\
\hline Current Eye Research & 3 & 1981 \\
\hline New England Journal Of Medicine & 3 & 1812 \\
\hline Rheumatology & 2 & 1952 \\
\hline $\begin{array}{l}\text { Arthritis \& Rheumatism-Arthritis Care \& } \\
\text { Research }\end{array}$ & 2 & 1988 \\
\hline Ocular Immunology And Inflammation & 2 & 1993 \\
\hline Nature & 2 & 1869 \\
\hline American Journal Of Medicine & 2 & 1946 \\
\hline Journal Of Clinical Investigation & 2 & 1925 \\
\hline Lancet & 1 & 1823 \\
\hline Archives Of Dermatology And Syphilology & 1 & 1922 \\
\hline Clinical And Experimental Ophthalmology & 1 & 1973 \\
\hline Annual Review Of Immunology & 1 & 1983 \\
\hline American Journal Of Gastroenterology & 1 & 1934 \\
\hline Emerging Infectious Diseases & 1 & 1995 \\
\hline Nature Medicine & 1 & 1995 \\
\hline Japanese Journal Of Cancer Research & 1 & 1985 \\
\hline $\begin{array}{l}\text { Retina-The Journal Of Retinal And Vitreous } \\
\text { Diseases }\end{array}$ & 1 & 1981 \\
\hline Science Translational Medicine & 1 & 2009 \\
\hline Ophthalmic Research & 1 & 1970 \\
\hline Journal Of Rheumatology & 1 & 1974 \\
\hline $\begin{array}{l}\text { Jama-Journal Of The American Medical } \\
\text { Association }\end{array}$ & 1 & 1883 \\
\hline International Ophthalmology & 1 & 1979 \\
\hline Journal Of Experimental Medicine & 1 & 1896 \\
\hline $\begin{array}{l}\text { Proceedings Of The National Academy Of } \\
\text { Sciences Of The United States Of America }\end{array}$ & 1 & 1915 \\
\hline Journal Of Expreimental Medicine & 1 & 1896 \\
\hline Rheumatology International & 1 & 1981 \\
\hline $\begin{array}{l}\text { Transactions Of The Ophthalmological } \\
\text { Societies Of The United Kingdom }\end{array}$ & 1 & 1880 \\
\hline
\end{tabular}

Articles originated from 13 countries, led by the United States of America $(n=52)$ followed by the Netherlands $(n=12)$, the United Kingdom ( $n=9)$, Japan ( $n=6)$, Germany and Australia (each $n=4)$, Turkey $(n=3)$, Canada and Spain (each $n=2$ ) and China, Switzerland Greece and France (each $n=1$ ) (Table 6). Fifty-four of the 60 articles (90\%) originated from the U.S. were published in American Journals and six (10\%) were published in British Journals.

Table 6: Countries from which the Articles in the Most-Cited List Originated.

\begin{tabular}{|c|c|}
\hline Country & No. of Articles \\
\hline U.S. & 52 \\
\hline The Netherlands & 12 \\
\hline U.K. & 9 \\
\hline Japan & 6 \\
\hline Australia & 4 \\
\hline Germany & 4 \\
\hline Turkey & 3 \\
\hline Canada & 2 \\
\hline Spain & 2 \\
\hline China & 1 \\
\hline Switzerland & 1 \\
\hline Greece & 1 \\
\hline France & 1 \\
\hline
\end{tabular}

Table 7: First and Last Authors with Multiple Articles in the Most-Cited List.

\begin{tabular}{|c|c|c|c|}
\hline $\begin{array}{c}\text { Frequent First } \\
\text { authors }\end{array}$ & No. of Articles & $\begin{array}{c}\text { Frequent } \\
\text { seniors authors }\end{array}$ & No. of Articles \\
\hline $\begin{array}{c}\text { NUSSENBLATT, } \\
\text { RB }\end{array}$ & 6 & KIJLSTRA, A & 9 \\
\hline DEVOS, AF & 3 & Caspi, RR & 6 \\
\hline ROTHOVA, A & 3 & Rosenbaum, JT & 5 \\
\hline Tugal-Tutkun, I & 3 & $\begin{array}{c}\text { NUSSENBLATT, } \\
\text { RB }\end{array}$ & 4 \\
\hline MOCHIZUKI, M & 2 & Foster, CS & 3 \\
\hline HELM, & 2 & HOLLAND, GN & 3 \\
\hline KANSKI, JJ & 2 & RAO, NA & 2 \\
\hline Jaffe, GJ & 2 & Rothova, A & 2 \\
\hline WACKER, WB & 2 & Wakefield, D & 2 \\
\hline Chang, JHM & 2 & MIYATA, N & 2 \\
\hline- & - & $\begin{array}{c}\text { Egwuagu, } \\
\text { Charles E }\end{array}$ & 2 \\
\hline- & - & WACKER, WB & 2 \\
\hline- & - & $\begin{array}{c}\text { Comstock, } \\
\text { Timothy L. }\end{array}$ & 2 \\
\hline- & - & GERY, I & 2 \\
\hline- & - & Whitcup, SM & 2 \\
\hline & & & \\
\hline & & & \\
\hline
\end{tabular}


There were ten authors with multiple first-authorships and fifteen authors with multiple last-authorships in the list of 100 most cited articles (Table 7). RB Nussenblatt had six first-authorships and four last-authorships and was thus the most-cited author in uveitis research. All of Nussenblatt'ssix first-authorship articles were cited a total of 1121 times (September 2016). The article entitled Standardization of uveitis nomenclature for reporting clinical data. A result of the First International Workshop (Jabs et al.) is the most cited article according to our analysis (total number of citations: 923).

\section{Discussion}

In this study, we recognized the authors and topics that have had the most impact in uveitis research over the past decades. We were able to gain an insight look in the uveitis research developments and its current progress through identifying these classic works.

The amount of citations an article has is a useful assessment of the impact one article either has or had on a certain topic. To assess an author's or journal's success, the number of citations has become a valuable tool $[9,15]$. Nonetheless, we highlight that the overall citation number refers mainly to the impact one article had during a certain period of time, instead of the quality of the article; still the most cited article began with zero citations. The longer a paper has been published, the more time it has to be cited. Consequently the highest-ranking articles might also be lead by the oldest articles [16]. But even landmark articles become less cited, because its content has become obsolete, forgotten or has been absorbed by current knowledge, which is described by Garfield as the phenomenon "obliteration by incorporation" [13]. Looking at our data, the overall citation rate increased in the recent years since the 1990s indicating the citation rate being independent from the publication date. This correlation was statistically significant $(r=0.41, p<0.001$, MannKendall test, Figure 4A). The increasing number of citations since the 1990 s could be linked to the rise of computers and increasing usage of the internet. (Figure 3) Submitted articles can be simultaneously reviewed by several people in the editorial team, and immediate feedback to the authors is possible, as is early online publication after article acceptance [6]. This significantly shortens the article submission to publication time and may subsequently attract more submissions [6]. The uveitis research has been evolving in recent years by treating the inflammation not only with steroids to alleviate the general inflammation in the eye but by targeting more specific cells, such as T-cells. Efficacy of the anti-TNF alpha agents has been established in the treatment of uveitis [17]. Local delivery systems, such as intravitreal injections of triamcinolone and sustained-release intravitreal implants are available and intravitreal injections of nanoparticles are under investigation [17]. This widens the field of uveitis treatment greatly with even more therapeutic options coming up. Previous studies have suggested that highly cited articles do not frequently have a high degree of evidence $[12,18,19]$. Browsing through the present study focusing on uveitis research disclosed that the greatest number of articles ( $n=26$, with a mean of $200 \pm 160$ citations per article) in the top 100 -listdo not largely consist a high level of evidence. These twenty-six publications represented Level-III clinical outcome studies. This supports the hypothesis that a novel concept presented in the form of small case series or cohort study can gain the attention of medical community [12].

By going through our data, it presents that most articles fall into the category of clinical research with $53 \%$ of all the articles out of the top-100 list. Of these they fall into two main subject areas, medical treatment $(n=20)$ and epidemiology $(n=17)$. In our analysis, the most cited articles in uveitis research affiliated (by the first author) with the U.S. (52\%), similar to the situation in other medical fields (e.g. general surgery [4], urology [20]). This might be based on several reasons. First, compared to Europe, the U.S. has a larger population size. Second, the U.S. tends to have larger research budgets [12] and last it has been shown that authors are prone to cite articles or journals from the same geographical region $[12,21]$. Correction on the basis of population size has been attempted by the authors of some bibliometric studies to eliminate that effect and thus gain clearer picture of the research activity of smaller countries while still revealing the impact of authors who have published multiple frequently cited articles $[12,22]$ With this, all articles from this list were published in thirty-five different journals. The majority $(n=55)$ of the top ranked articles were published in the top six journals with four originating in the U.S. and one originating each in the Netherlands and the U.K. Furthermore, most of these thirty-five journals originated in the U.S. (51.4\%), followed by the U.K with $14.3 \%$. In our study, the most cited uveitis articles from the U.S. were published in American journals. Articles from other countries were also published almost exclusively in journals of their country of origin. English language journals have the highest rank in ophthalmology, which results in a high attractiveness for authors with highly ranked material and contributes to the predominant standing of these Journals. The top five senior authors from the 100 most-cited papers in uveitis research contributed to 27 articles and accumulated a total of 5478 citations, or $28 \%$ of all citations ( $n=27$, median: 140 range: 106 to 923). Sixteen of these articles were from the U.S., 6 from the Netherlands, 3 from Britain and 1 each from Australia and Turkey. These articles highlight how a relatively small cohort of authors can substantially contribute to the impact of a journal or a field of research [6]. The article entitled Standardization of uveitis nomenclature for reporting clinical data. Results of the First International Workshop (Jabs et al.) is according to our analysis the most-cited paper in uveitis research (total count of citations: 923).

Although bibliometric studies provide a valuable snapshot of articles that have attracted citations, it is important to keep in 
mind that treatment philosophies change, especially in rapidly developing fields such as ophthalmology, and not every article that had once been of importance has the same value today [12] We know there are limitations in citation analysis when relying solely upon total citation counts. This is because there is a bias towards journals with large publication volumes, and citation analysis assumes all citations are of a positive nature, while citation reports depend on data aggregated from a selected database (in this study, the ISI Web of Knowledge) [6]. By selecting on the basis of a different definition of a classiccould contribute to different lists of results. We follow Ahmad et al. [12] by emphasizing the requirement to refer to our ranking as "citation classics"- as a tool for quantifying the individual impact of articles in bibliometric studies.

To our best knowledge, this is the first to identify the top100 list in the field of bibliometric uveitis research. Despite its limitations, citation analysis remains one of the best currently available tools for quantifying the impact of scientific articles on their field [12]. Periodic updates of bibliometric studies are necessary to include the more recent rising stars. [12,23] Our present study demonstrates that the majority $(n=54)$ of the top ranked articles were published in six of the top ranked journals. Four of these journals originated in the U.S. and one each of these originated in the Netherlands and the U.K."Medical treatment" and "Epidemiology" were the two subareas of clinical research which the large part of these articles focused on. Younger case studies had higher citation rate (in 2015) as older studies. The biggest portion of articles represented Level-III clinical outcome studies implicating that even smaller case series or cohort studies could gain attention.

\section{References}

1. Fan JC, McGhee CN. Citation analysis of the most influential authors and ophthalmology journals in the field of cataract and corneal refractive surgery 2000-2004.ClinExpOphthalmol 2008;36:54-61.

2. Kelly JC, Glynn RW, O’Brien DE, Felle P, McCabe JP.The 100 classic papers of orthopaedic surgery: a bibliometric analysis. J Bone Joint Surg Br 2010;92:1338-43.

3. Skovrlj B, Steinberger J, Guzman JZ, Overley SC, Qureshi SA, Caridi JM, Cho SK. The 100 Most Influential Articles in Cervical Spine Surgery. Global Spine J 2016;6:69-79.

4. Paladugu R, Schein M, Gardezi S, Wise L. One hundred citation classics in general surgical journals. World J Surg. 2002;26(9):1099-1105. doi:10.1007/s00268-002-6376-7.

5. Sims JL, McGhee CNJ. Citation analysis and journal impact factors in ophthalmology and vision science journals. Clin Experiment Ophthalmol. 2003;31(1):14-22.
6. Chou CY, Chew SS, Patel DV, Ormonde SE, McGhee CNj. Publication and citation analysis of the Australian and New Zealand Journal of Ophthalmology and Clinical and Experimental Ophthalmology over a 10-year period: the evolution of an ophthalmology journal. ClinExp0phthalmol 2009;37:868-73.

7. Tao T, Zhao X, Lou J, Bo L, Wang F, Li J, Deng X. The top cited clinical research articles on sepsis: a bibliometric analysis. Crit Care. 2012;16(3):R110. doi:10.1186/cc11401.

8. Ye S, Xing R, Liu J, Xing F. Bibliometric analysis of Nobelists' awards and landmark papers in physiology or medicine during 1983-2012. Ann Med. 2013;45(8):532-538. doi:10.3109/07853890.2013.850838.

9. Garfield E. The history and meaning of the journal impact factor. JAMA. 2006;295(1):90-93. doi:10.1001/jama.295.1.90.

10. Garfield E. Journal impactfactor: a brief review.CMAJ.1999;161(8):979980.

11. Garfield E. [The impact factor and its rightful use]. Anaesthesist. 1998;47(6):439-440. doi:10.1007/s001010050581.

12. Ahmad SS, Evangelopoulos DS, Abbasian M, Röder C, Kohl S. The hundred most-cited publications in orthopaedic knee research. J Bone Joint Surg Am 2014;96:e190.

13. Garfield E. 100 citation classics from the Journal of the American Medical Association. JAMA 1987;257:52-9

14. Steinberger J, Skovrlj B, Caridi JM, Cho SK. The top 100 classic papers in lumbar spine surgery. Spine (Phila Pa 1976) 2015;40:740-7.

15. Garfield E. Citation indexes for science; a new dimension in documentation through association of ideas. Science 1955; 122:10811.

16. Picknett T, Davis K. The 100 most-cited articles from JMB. J Mol Biol. 1999;293(2):171-176. doi:10.1006/jmbi.1999.3148.

17. Susan Wittenberg. https://www.aao.org/young-ophthalmologists/ yo-info/article/10-clinical-pearls-treating-uveitis\#related-comments, accessed $24^{\text {th }}$ of January 2017

18. Namdari S, Baldwin K, Kovatch K, Huffman GR, Glaser D. Fifty most cited articles in orthopedic shoulder surgery. Journal of Shoulder and Elbow Surgery. 2012;21(12):1796-1802. doi:10.1016/j.jse.2011.11.040.

19. Murray MR, Wang T, Schroeder GD, Hsu WK. The 100 most cited spine articles. Eur Spine J. 2012;21(10):2059-2069. doi:10.1007/s00586012-2303-2.

20. Hennessey K, Afshar K, Macneily AE. The top 100 cited articles in urology. Can UrolAssoc J 2009;3:293-302.

21. Narin F, Hamilton KS. Bibliometric performance measures. Scientometrics. 1996;36(3):293-310. doi:10.1007/BF02129596.

22. Fendrich V, Rothmund M. Surgical research in Germany-an international comparison. Chirurg 2010;81:328-33.

23. Nason GJ, Tareen F, Mortell A. The top 100 cited articles in urology: An update. Canadian Urological Association Journal. 2013;7(1-2):16-24. doi:10.5489/cuaj.189. 
This work is licensed under Creative Commons Attribution 4.0 License DOI: 10.19080/JOJO.2018.06.555696
Your next submission with Juniper Publishers will reach you the below assets

- Quality Editorial service

- Swift Peer Review

- Reprints availability

- E-prints Service

- Manuscript Podcast for convenient understanding

- Global attainment for your research

- Manuscript accessibility in different formats

( Pdf, E-pub, Full Text, Audio)

- Unceasing customer service

Track the below URL for one-step submission https://juniperpublishers.com/online-submission.php 